\title{
A Basis for Agrocin 84 Sensitivity in Agrobacterium radiobacter
}

\author{
By P. J. MURPHY AND W. P. ROBERTS* \\ Departments of Agricultural Biochemistry and Plant Pathology, \\ Waite Agricultural Research Institute, Glen Osmond, South Australia \\ 5064, Australia
}

(Received 13 November 1978; revised 20 February 1979)

\begin{abstract}
Agrocin 84 inhibits a virulent strain of Agrobacterium radiobacter containing a nopaline Ti plasmid, but not the same strain lacking the Ti plasmid; this specificity was investigated. Sensitivity to agrocin 84 was correlated with its active uptake by a high-affinity transport system with a $K_{\mathrm{m}}$ of $5.88 \times 10^{-8} \mathrm{M}$. Unmetabolized agrocin 84 was transported inside the sensitive strain and was associated with the soluble fraction of ruptured bacteria and not with the outer walls or cytoplasmic membrane. Agrocin 84 bound to a protein fraction isolated from the periplasmic space of the sensitive strain; there was no equivalent binding activity in the insensitive strain. It is proposed that sensitivity to agrocin 84 is due to the presence of one or more plasmid-coded binding proteins which are associated with transport of agrocin 84 into sensitive strains.
\end{abstract}

\section{INTRODUCTION}

Crown gall is a neoplastic disease of plants induced by virulent strains of Agrobacterium radiobacter. In stone fruit, the disease is controlled biologically by dipping planting material in a cell suspension of an avirulent strain of $A$. radiobacter K84 (New \& Kerr, 1972) which produces agrocin 84 , a low molecular weight bacteriocin characterized as a fraudulent adenine nucleotide (Roberts et al., 1977). The primary site of action of agrocin 84 has not yet been determined although McCardell \& Pootjes (1976) demonstrated a major effect on DNA and protein synthesis.

The genes coding for sensitivity to agrocin 84 are located on the Ti plasmid, which also codes for virulence and nopaline metabolism (Van Larebeke et al., 1975; Watson et al., 1975). Avirulent strains lacking a Ti plasmid are not sensitive to agrocin 84 (Van Larebeke et al., 1975; Watson et al., 1975). The Ti plasmid is a conjugative plasmid and can be readily transmitted from virulent donor to avirulent recipient strains of $A$. radiobacter. The coded characters of virulence, nopaline metabolism and agrocin 84 sensitivity are also transmitted and expressed (Van Larebeke et al., 1975; Watson et al., 1975).

The extraordinary selectivity of agrocin 84 for virulent strains of $A$. radiobacter carrying a nopaline Ti plasmid forms the subject of this paper.

\section{METHODS}

Bacterial strains. Four strains of $A$. radiobacter were used: $\mathrm{K} 57$, an avirulent strain insensitive to agrocin 84; K57A, the same strain after acquisition of a Ti plasmid following a Kerr cross (Kerr, 1971), sensitive to agrocin $84 ; \mathrm{K} 24$, a virulent wild-type strain sensitive to agrocin 84 (our standard indicator strain for agrocin 84 production); K229, a rough colony variant of K84 which produces agrocin 84 .

Media. The medium used for production of agrocin 84 contained (per litre): $\left(\mathrm{NH}_{4}\right) \mathrm{SO}_{4}, 1.0 \mathrm{~g}$; trisodium

* Present address: Department of Microbiology, La Trobe University, Bundoora, Victoria 3083, Australia. 
citrate, $0.5 \mathrm{~g}$; sodium glutamate, $1.0 \mathrm{~g} ; \mathrm{K}_{2} \mathrm{HPO}_{4}, 1.05 \mathrm{~g} ; \mathrm{KH}_{2} \mathrm{PO}_{4}, 0.45 \mathrm{~g} ; \mathrm{Fe}\left(\mathrm{NO}_{3}\right)_{3}, 5 \mathrm{mg}$; biotin, $200 \mu \mathrm{g}$; trace elements (Gamborg \& Eveleigh, 1968), 1.0 ml; and (added as separately sterilized solutions) glucose, $2.0 \mathrm{~g}$; $\mathrm{MgSO}_{4} .7 \mathrm{H}_{2} \mathbf{0}, 0.2 \mathrm{~g}$; thiamin, $5 \mathrm{mg}$; the final $\mathrm{pH}$ was $7 \cdot 0$. Strain $\mathrm{K} 229$ was inoculated and incubated on an orbital shaker for $48 \mathrm{~h}$ at $25^{\circ} \mathrm{C}$. For the preparation of $\left[{ }^{32} \mathrm{P}\right]$ agrocin 84 , the phosphate concentration was reduced to $1 \mu \mathrm{g} \mathrm{ml}^{-1}$ and 5 to $10 \mu \mathrm{Ci}^{32} \mathrm{P} \mathrm{ml}^{-1}$ was added after $24 \mathrm{~h}$ incubation. Agrocin 84 used for viability studies was prepared by incubating strain K229 as described above, removing the bacteria by centrifugation and sterilizing the supernatant by shaking with 0.5 vol. chloroform.

To determine the numbers of viable bacteria, samples were plated on Yeast Mannitol Agar (YMA) and incubated at $27^{\circ} \mathrm{C}$.

Chemicals. Carbenicillin was obtained from Beecham Research Laboratories; egg white lysozyme from Sigma. ${ }^{32} \mathrm{P}$ as orthophosphate was obtained from the Australian Atomic Energy Commission. The charcoal used was Nuchar Granular C (ash content, 2.95\%; Fe, 0.11\%). All other chemicals were analytical grade.

Protein determination. Protein concentrations were determined by Lowry's method, using bovine serum albumin as a standard. Where necessary, initial precipitation with $5 \%(\mathrm{w} / \mathrm{v})$ trichloroacetic acid preceded protein determination.

Purification of $\left[{ }^{32} \mathrm{P}\right]$ agrocin 84 . Batches of $100 \mathrm{ml}{ }^{32} \mathrm{P}$-labelled culture medium were stirred with $0.5 \mathrm{~g}$ charcoal at $4{ }^{\circ} \mathrm{C}$ for $24 \mathrm{~h}$. The charcoal was removed by centrifugation $(17000 \mathrm{~g}, 10 \mathrm{~min})$ and stirred at $4{ }^{\circ} \mathrm{C}$ with two changes of $100 \mathrm{ml} 70 \%(\mathrm{v} / \mathrm{v})$ ethanol over $24 \mathrm{~h}$. The pooled ethanol fractions were rotary evaporated at $35^{\circ} \mathrm{C}$, lyophilized, made up in $1 \mathrm{ml}$ water and applied as a band to $3 \mathrm{MM}$ Whatman paper and subjected to electrophoresis (Tate, 1968); the buffer was triethylamine acetate, $\mathrm{pH} 5 \cdot 0$ [containing triethylamine $\left(9.71 \mathrm{ml} \mathrm{l}^{-1}\right)$ and glacial acetic acid $\left(5.72 \mathrm{ml} \mathrm{l}^{-1}\right]$. A thin strip of the electrophoretogram was bioassayed for agrocin 84 activity. Agrocin 84 was eluted with water and subjected to further electrophoresis in triethylamine borate buffer, $\mathrm{pH} 9.4$ [containing triethylamine $\left(14.0 \mathrm{ml} \mathrm{l}^{-1}\right)$ and boric acid $\left(12.36 \mathrm{~g} \mathrm{l}^{-1}\right)$ ]. A thin strip of the electrophoretogram was scanned for ${ }^{32} \mathrm{P}$ activity on a Packard Radiochromatogram Scanner as well as bioassayed. The band corresponding to a single peak of ${ }^{32} \mathrm{P}$ activity, and also to biological activity, was eluted in water and stored at $4{ }^{\circ} \mathrm{C}$. Agrocin 84 used to quantify kinetic studies was purified as outlined by Roberts et al. (1977).

Uptake studies. Cultures were grown overnight in Stonier's medium (Stonier, 1956) and then resuspended in fresh medium to give an $A_{640}$ of 0.6 in a $1 \mathrm{~cm}$ cuvette. Portions $(1 \mathrm{ml})$ of this bacterial suspension were maintained at $25^{\circ} \mathrm{C}$ for $10 \mathrm{~min}$, then [ ${ }^{32} \mathrm{P}$ ]agrocin 84 was added and samples $(2 \times 50 \mu \mathrm{l})$ were taken at the times indicated. These samples were immediately filtered through Sartorius membranes $(0.45 \mu \mathrm{m}$ pore size $)$ and the membrane and residue were washed with Stonier's medium $(2 \times 5 \mathrm{ml})$, placed in a scintillation vial and dried at $110^{\circ} \mathrm{C}$ for $10 \mathrm{~min}$. Scintillant [ $2 \mathrm{ml}$; containing 1,4-bis-2-(4-methyl-5-phenyloxazolyl)benzene (dimethyl-POPOP, $0 \cdot 3 \mathrm{~g}^{-1}$ ) and 2,5-diphenyloxazole (PPO, $8 \mathrm{~g} \mathrm{l}^{-1}$ )] was added to each vial and the radioactivity was counted in a Packard Tricarb scintillation counter. When inhibitors were added to cultures, the bacteria were preincubated with the inhibitor for $15 \mathrm{~min}$ before [ ${ }^{32} \mathrm{P}$ ]agrocin 84 was added.

For kinetic studies, strain K57A was grown overnight in Stonier's medium and then resuspended to give an $A_{640}$ of 0.15 in a $1 \mathrm{~cm}$ cuvette. Portions $(1 \mathrm{ml})$ were taken and incubated at $25^{\circ} \mathrm{C}$ for $5 \mathrm{~min}$ before [ $\left.{ }^{32} \mathrm{P}\right]-$ agrocin 84 was added. Samples $(50 \mu \mathrm{l})$ were removed at 30 and $60 \mathrm{~s}$ intervals, filtered and counted as above. The amount of agrocin 84 present was calculated by comparison with a standard solution of known absorbance at $264 \mathrm{~nm}$ and a molar extinction coefficient of 19860 (Roberts et al., 1977).

Preparation of protein fractions. Protein extracts were prepared from $500 \mathrm{ml}$ cultures grown in Stonier's medium for $48 \mathrm{~h}$ at $25^{\circ} \mathrm{C}$ on an orbital shaker. The cultures were centrifuged at $6000 \mathrm{~g}$ for $10 \mathrm{~min}$ and then resuspended in $0 \cdot 1 \mathrm{M}$-phosphate buffer pH 7.0 [containing $\mathrm{NaH}_{2} \mathrm{PO}_{4} \cdot 2 \mathrm{H}_{2} \mathrm{O}\left(7 \cdot 8 \mathrm{~g} \mathrm{l}^{-1}\right)$ and $\mathrm{Na}_{2} \mathrm{HPO}_{4} \cdot 2 \mathrm{H}_{2} \mathrm{O}$ $\left.\left(8.9 \mathrm{~g}^{-1}\right)\right]$ to form a thick slurry. The bacteria were disrupted by three passages through a French pressure cell at $17.5 \mathrm{MPa}$. Whole bacteria were removed by centrifugation at $7500 \mathrm{~g}$ for $10 \mathrm{~min}$ at $4{ }^{\circ} \mathrm{C}$. The supernatant was then filtered through Sartorius membrane filters $(0.45 \mu \mathrm{m}$ pore size) to remove all bacteria and tested for sterility by plating on to YMA plates.

To produce periplasmic protein fractions, spheroplasts of $A$. radiobacter were made. This was done by a modification of the method of Klapwijk et al. (1975) used to lyse bacteria. Cultures were grown overnight in Stonier's medium and then resuspended in fresh medium to an $A_{640}$ of $0 \cdot 6$. Sucrose $\left(0 \cdot 171 \mathrm{~g} \mathrm{ml}^{-1}\right)$, carbenicillin $\left(500 \mu \mathrm{g} \mathrm{ml}^{-1}\right)$ and lysozyme $\left(100 \mu \mathrm{g} \mathrm{ml}^{-1}\right)$ were added and the cultures were incubated for a further $4 \mathrm{~h}$. The bacteria so produced were susceptible to osmotic lysis, and the formation of spheroplasts with intact cytoplasm but modified outer cell walls and periplasmic space was verified by electron microscopy. In some preparations, up to $25 \%$ ghost bacteria were present. After centrifugation $(5000 \mathrm{~g}, 15 \mathrm{~min}$, $4{ }^{\circ} \mathrm{C}$ ) the supernatant was removed and concentrated approximately 25 -fold by filtering through an Amicon PM-10 filter. This fraction was designated the periplasmic fraction. The pellet was resuspended in $0 \cdot 1 \mathrm{M}-$ phosphate buffer pH 7.0 and the bacteria were disrupted by three passages through a French pressure cell at $17.5 \mathrm{MPa}$. After centrifugation $\left(12000 \mathrm{~g}, 10 \mathrm{~min}, 4^{\circ} \mathrm{C}\right)$ the supernatant was collected. This fraction was designated the cytoplasmic fraction. 


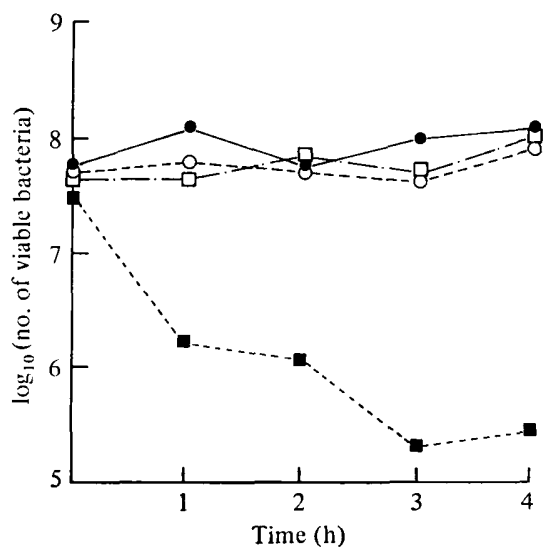

Fig. 1. Effect of agrocin 84 on the viability of avirulent and virulent $A$, radiobacter strains. Avirulent strain K57: 0 , control; $\square$, with agrocin 84. Virulent strain K57A: $O$, control; $\square$, with agrocin 84. (Agrocin 84: $7 \times 10^{-7} \mathrm{M}$ )

Binding assays. Agrocin 84 binding assays were performed using dialysis chambers made of $5 \mathrm{ml}$ glass tubes in which $8 / 32$ Visking dialysis tubing was placed. Stirring was by small magnetic stirrers. The protein sample $(0.5 \mathrm{ml})$ was placed inside the dialysis bag; $3 \mathrm{ml} 0.1 \mathrm{M}$-phosphate buffer $\mathrm{pH} 7.0$, to which [ ${ }^{32} \mathrm{P}$ ]agrocin 84 (about 30000 c.p.m.) was added, was in the outside chamber. Dialysis equilibrium was attained after $24 \mathrm{~h}$ at $4{ }^{\circ} \mathrm{C}$. Samples from inside and outside the bag were then taken and dried on glass fibre before counting in scintillant as previously described.

Bioassay. The bioassay technique was a modification of the method originally developed by Stonier (1960). Plates of Stonier's medium containing $1 \cdot 3 \%(\mathrm{w} / \mathrm{v})$ agar were poured to give $3 \mathrm{~mm}$ thickness; a well ( $5 \mathrm{~mm}$ diam.) was cut in the agar and $20 \mu \mathrm{l}$ agrocin 84 was added. This was left to diffuse for $3 \mathrm{~h}$, during which time the plate was sterilized with chloroform, before the indicator strain was overlaid in buffered agar. Plates were incubated at $27^{\circ} \mathrm{C}$ and the diameters of inhibition zones were measured after $48 \mathrm{~h}$.

\section{RESULTS}

\section{Effect of agrocin 84 on virulent and avirulent strains}

The addition of non-purified agrocin 84 to pre-exponential phase cultures of the virulent strain $\mathrm{K} 57 \mathrm{~A}$ and the avirulent strain $\mathrm{K} 57$ resulted in the selective reduction of viability of K57A but had no measurable effect on K57 (Fig. 1).

\section{Uptake of agrocin 84}

When strain K57A was incubated in the presence of [32 P]agrocin 84 , there was a rapid uptake of the bacteriocin which continued until a maximum level was reached at $2 \mathrm{~h}$. Strain K57 showed negligible uptake of agrocin 84 (Fig. 2). The uptake of agrocin 84 into cells of the sensitive strain followed Michaelis-Menten kinetics; the uptake was by a highaffinity system with a $K_{\mathrm{m}}$ of $5.88 \times 10^{-8} \mathrm{M}$. To determine whether the absence of uptake in strain K57 was due to a breakdown of agrocin 84, strain K57 was incubated with the bacteriocin for $2 \mathrm{~h}$ and then the incubation medium was examined by electrophoresis. No significant degradation of bacteriocin was observed.

\section{Effect of temperature and metabolic inhibitors on the uptake of agrocin 84}

When strain K57A was incubated at $0{ }^{\circ} \mathrm{C}$ there was no uptake of agrocin 84 (Fig. 3). On re-incubation at $25^{\circ} \mathrm{C}$, there was an immediate uptake at the same rate as with bacteria continuously incubated at $25^{\circ} \mathrm{C}$, indicating that the bacteria were not damaged by this treatment. Figure 4 shows the effect of some metabolic inhibitors on uptake of agrocin 84 by sensitive bacteria. Both sodium azide and dinitrophenol at $10 \mathrm{~mm}$ greatly reduced the 


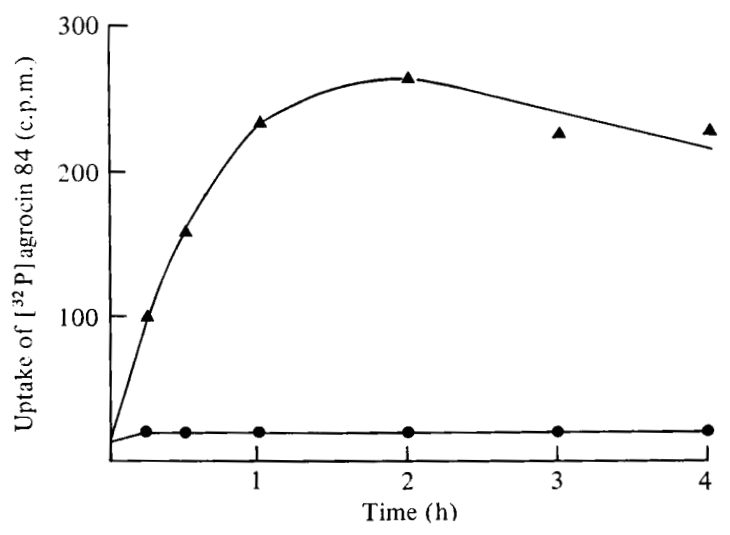

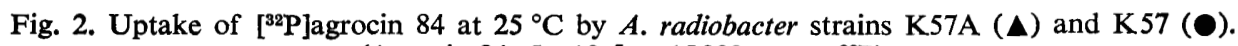
(Agrocin 84: $5 \times 10^{-7} \mathrm{M}, 15000$ c.p.m. ${ }^{32} \mathrm{P}$ )

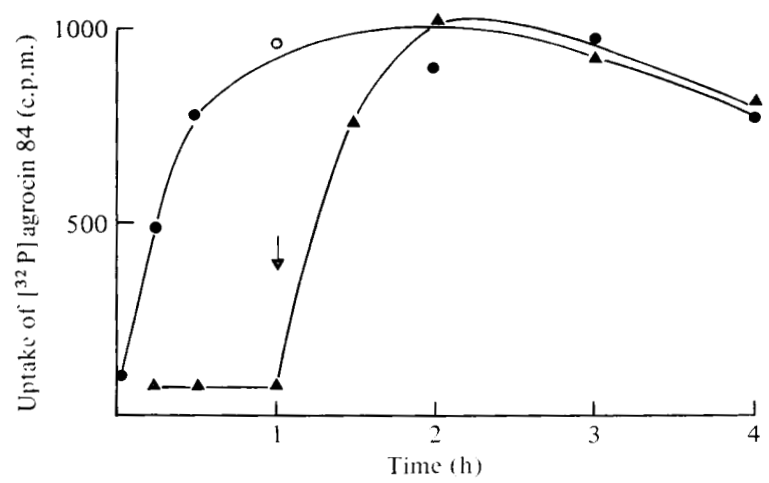

Fig. 3. Effect of temperature on the uptake of $\left[{ }^{32} \mathrm{P}\right]$ agrocin 84 by $A$. radiobacter strain K57A: control, incubated in Stonier's medium at $25^{\circ} \mathrm{C} ; \boldsymbol{\Delta}$, incubated at $0{ }^{\circ} \mathrm{C}$ for $1 \mathrm{~h}$ and then transferred to $25^{\circ} \mathrm{C}$ (arrow). (Agrocin 84: $5 \times 10^{-7} \mathrm{M}, 40000$ c.p.m. ${ }^{32} \mathrm{P}$ )

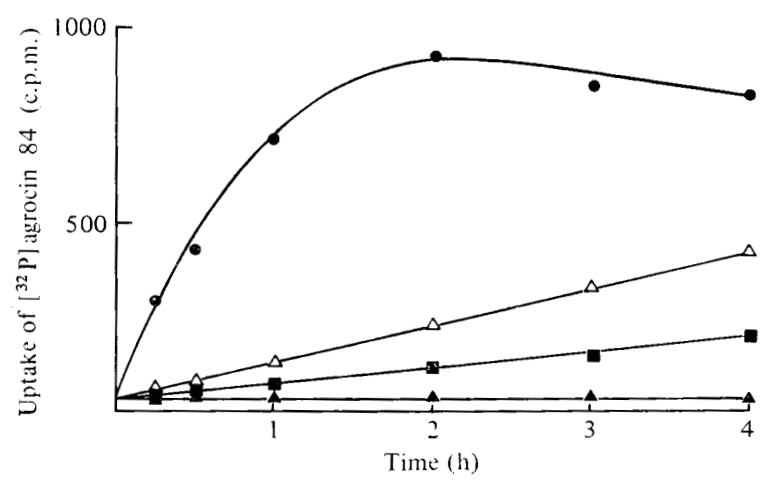

Fig. 4. Inhibition of $\left.{ }^{32} \mathrm{P}\right]$ agrocin 84 uptake by $A$. radiobacter strain K57A at $25^{\circ} \mathrm{C}$ : $\bullet$, control (no inhibitor); $\triangle, 100 \mu \mathrm{M}$-dicyclohexylcarbodiimide; $\square, 10 \mathrm{~mm}$-dinitrophenol; $\Delta, 10 \mathrm{~mm}$-sodium azide. (Agrocin 84: $5 \times 10^{-7} \mathrm{M}, 40000$ c.p.m. ${ }^{32} \mathrm{P}$ ) 


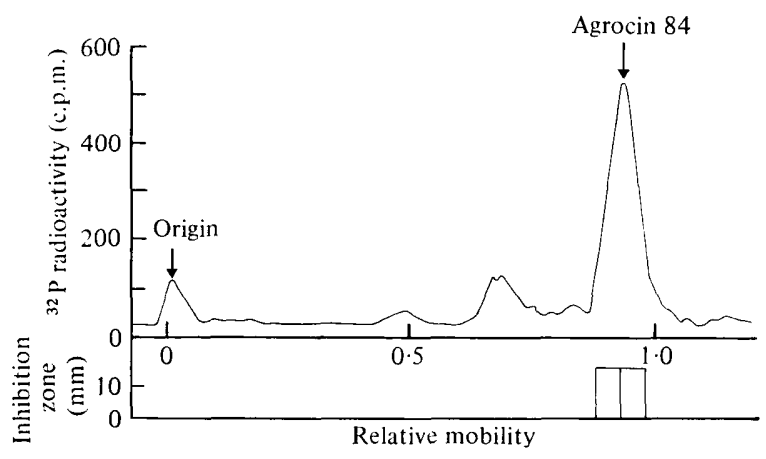

Fig. 5. Agrocin 84 and its degradation products extracted from $A$. radiobacter strain K57A. Bacteria were incubated with [ ${ }^{32} \mathrm{P}$ ]agrocin 84 for $2 \mathrm{~h}$, washed four times with Stonier's medium and then sonicated. The extract was centrifuged to remove broken cell components and the supernatant was subjected to electrophoresis in $\mathrm{Na}_{2} \mathrm{~B}_{4} \mathrm{O}_{7} ;$ mobilities were determined relative to the markers 2-deoxyadenosine $(0 \cdot 0)$ and orange $G(1 \cdot 0)$. The electrophoretogram was scanned for ${ }^{32} P$ and bioassayed for agrocin 84 activity.

Table 1. Equilibrium dialysis binding of agrocin 84 to cytoplasmic and periplasmic fractions of Agrobacterium radiobacter

Cytoplasmic and periplasmic fractions of $A$. radiobacter were prepared as described in Methods (using $500 \mu \mathrm{g}$ carbenicillin $\mathrm{ml}^{-1}$ and $100 \mu \mathrm{g}$ lysozyme $\mathrm{ml}^{-1}$ in experiment 1 , and $500 \mu \mathrm{g}$ carbenicillin $\mathrm{ml}^{-1}$ only in experiment 2). Binding of agrocin 84 was determined by equilibrium dialysis.

$\begin{array}{llcc}\text { Strain } & \text { Fraction } & \overbrace{\text { Expt 1 }}^{\text {[c.p.m. (mg protein)-1] }} \\ \text { K57A } & \text { Cytoplasmic } & 1990 & \text { Expt 2 } \\ \text { K57A } & \text { Periplasmic } & 7885 & 2336 \\ \text { K57 } & \text { Cytoplasmic } & 1845 & 5000 \\ \text { K57 } & \text { Periplasmic } & 709 & 2328 \\ \text { S2P bound } & 0\end{array}$

uptake of agrocin 84. Dicyclohexylcarbodiimide at $100 \mu \mathrm{M}$ also reduced the uptake of agrocin 84 , but not to the same extent as the other inhibitors which were used at higher concentrations.

\section{Transport of agrocin 84 into sensitive bacteria}

Sensitive bacteria which had previously been incubated in the presence of $\left.{ }^{32} \mathrm{P}\right]$ agrocin 84 for $2 \mathrm{~h}$ at $25^{\circ} \mathrm{C}$ were washed and then sonicated. Nearly $90 \%$ of the radioactivity remained in the supernatant fraction after centrifugation at $37000 \mathrm{~g}$ for $30 \mathrm{~min}$ to remove walls and membrane components (Sykes, 1971). Centrifugation at $160000 \mathrm{~g}$ for $4 \mathrm{~h}$ did not alter this distribution. Electrophoresis of the supernatant fraction yielded a major peak corresponding to free unbound agrocin 84 (Fig. 5). This peak also retained biological activity. Other minor peaks which have not yet been characterized were also found, in particular a non-mobile peak.

\section{An agrocin 84 binding protein}

As measured by equilibrium dialysis, agrocin 84 was bound to whole cell extracts of both sensitive and insensitive bacteria, but the specific activity of binding was about twofold higher for the sensitive strain. Removal of membrane particles and organelles by centrifugation at $200000 \mathrm{~g}$ for $2 \mathrm{~h}$ did not alter the specific activity of binding. When the cell extracts of both sensitive and insensitive strains were incubated with $1 \mathrm{mg}$ protease $\mathrm{ml}^{-1}$ for $3 \mathrm{~h}$ at $37^{\circ} \mathrm{C}$, which resulted in an $80 \%$ reduction in protein level, binding was eliminated indicating that agrocin 84 was binding to a protein component. 


\section{Localization of the agrocin 84 binding protein}

To determine the location of the agrocin 84 binding protein, protein extracts from the periplasmic space and cytoplasm of $A$. radiobacter were made and tested by equilibrium dialysis. Table 1 shows the specific activity of binding of agrocin 84 to periplasmic and cytoplasmic fractions of both sensitive and insensitive strains.

\section{DISCUSSION}

Selective inhibition (Fig. 1) of the converted pathogenic $A$. radiobacter strain K57A by agrocin 84 , while growth of its unconverted non-pathogenic precursor strain $\mathrm{K} 57$ is unaffected, confirms the earlier work on selectivity of agrocin 84 using plate bioassays (Roberts \& Kerr, 1974). In addition, Fig. 2 shows that this extraordinarily selective growth inhibition, which is characteristic of bacteriocins (Reeves, 1972), is a consequence of a selective uptake of agrocin 84 by the sensitive pathogenic strain K57A.

At $0{ }^{\circ} \mathrm{C}$ (Fig. 3) no uptake of agrocin 84 was observed, demonstrating that an actively metabolizing cell is an essential pre-requisite for uptake. This observation was further supported by studies (Fig. 4) with the respiratory inhibitors sodium azide and dinitrophenol which are known to interfere with oxidative phosphorylation and which also markedly inhibit the uptake of agrocin 84. Likewise dicyclohexylcarbodiimide also inhibits the uptake of agrocin 84 and is known to interfere with ATPase function (Altendorf \& Zitzmann, 1975).

Equilibrium dialysis studies of the binding of [ $\left.{ }^{32} \mathrm{P}\right]$ agrocin 84 showed that periplasmic protein extracts from the sensitive strain $\mathrm{K} 57 \mathrm{~A}$ bound agrocin 84 , whereas there was little or no binding (depending on the extraction method used) to periplasmic protein extracts of the insensitive strain. Agrocin 84 was bound equally well to cytoplasmic extracts from both sensitive and insensitive strains; this probably represents non-specific binding.

Our results provide no evidence for irreversible binding of agrocin 84 to wall components or any other organelle; this is in marked contrast to most other known bacteriocins such as the colicins (Reeves, 1972). Since the bulk of the intracellular bacteriocin is unbound (Fig. 5), it is likely that the periplasmic binding protein(s) (Table 1) are concerned with transport into the bacterium, and as such the observed binding would be a reversible phenomenon; unpublished results supports this suggestion.

The unique selectivity of agrocin 84 possibly resides in the presence of specific binding protein(s) in the sensitive strain K57A which is released into the surrounding medium in the presence of carbenicillin and is presumably periplasmic in origin. It is generally accepted that periplasmic proteins are involved in the uptake of a variety of low molecular weight substances (Boos, 1974). We suggest that agrocin 84 is the first recorded member of a new class of highly selective low molecular weight nucleotide bacteriocins. These nucleotide bacteriocins may be characterized by uptake of the bacteriocin rather than adsorption to the cell surface and by the presence in sensitive strains of specific receptor protein(s). Subsequent to uptake the intact bacteriocin may be metabolized intracellularly.

As the difference between non-pathogenic strains and converted pathogenic strains is known to be due to the presence in the latter of a large plasmid, it seems likely that the specific receptor protein(s) in the pathogenic strain K57A is plasmid-coded. During the preparation of this manuscript, the isolation of two plasmid-coded periplasmic proteins from A. tumefaciens C-58, a virulent strain sensitive to agrocin 84 , was reported. The avirulent plasmid-free derivatives of this strain, which is not sensitive to agrocin 84 , did not possess these proteins (Sonoki \& Kado, 1978).

This work was partly sponsored by the Commonwealth Postgraduate Scholarship Scheme. We appreciate stimulating discussions with Drs A. Kerr and M. E. Tate. 


\section{REFERENCES}

Altendorf, K. \& Zitzman, W. (1975). Identification of the DCCD-reactive protein of the energy transducing adenosinetriphosphatase complex from Escherichia coli. FEBS Letters 59, 268-272.

Boos, W. (1974). Bacterial transport. Annual Review of Biochemistry 43, 123-146.

Gamborg, O. L. \& Eveleigh, D. E. (1968). Culture methods and detection of glucanases in suspension cultures of wheat and barley. Canadian Journal of Biochemistry 46, 417-421.

KERR, A. (1971). Acquisition of virulence by nonpathogenic isolates of Agrobacterium radiobacter. Physiological Plant Pathology 1, 241-246.

KlaPWIJK, P. M., DE JONGE, A. J. R., SCHILPEROORT, R. A. \& RöRSCH, A. (1975). An enrichment technique for auxotrophs of Agrobacterium tumefaciens using a combination of carbenicillin and lysozyme. Journal of General Microbiology 91, 177-182.

McCardell, B. A. \& Pootjes, C. F. (1976). Chemical nature of agrocin 84 and its effect on a virulent strain of Agrobacterium tumefaciens. Antimicrobial Agents and Chemotherapy 10, 498-502.

New, P. B. \& KerR, A. (1972). Biological control of crown gall: field measurements and glasshouse experiments. Journal of Applied Bacteriology 35, 279-287.

REEVES, P. (1972). The Bacteriocins. New York: Springer-Verlag.

ROBERTS, W. P. \& KerR, A. (1974). Crown gall induction: serological reactions, isozyme patterns and sensitivity to mitomycin $\mathbf{C}$ and to bacteriocin, of pathogenic and non pathogenic strains of
Agrobacterium radiobacter. Physiological Plant Pathology 4, 81-92.

Roberts, W. P., TAte, M. E. \& Kerr, A. (1977). Agrocin 84 is a 6- $N$-phosphoramidate of an adenine nucleotide analogue. Nature, London 265, 379-381.

SonOKI, S. \& Kado, C. I. (1978). Proteins conferred by the virulence-specifying plasmid of Agrobacterium tumefaciens C-58. Proceedings of the National Academy of Sciences of the United States of America 75, 3796-3800.

Stonier, T. (1956). Labelling crown gall bacteria with ${ }^{32} \mathrm{P}$ for radioautography. Journal of Bacteriology 72, 259-268.

Stonier, T. (1960). Agrobacterium tumefaciens. II. Production of an antibiotic substance. Journal of Bacteriology 79, 889-898.

SykeS, J. (1971). Centrifugal techniques for the isolation and characterization of sub-cellular components from bacteria. Methods in Microbiology 5B, 55-207.

TATE, M. E. (1968). Separation of myoinositol pentaphosphates by moving paper electrophoresis (MPE). Analytical Biochemistry 23, 141-149.

Van Larebeke, N., Genetello, Ch., Schell, J., Schilperoort, R. A., Hermans, H., HernalSteens, J. P. \& VAN Montagu, M. (1975). Acquisition of tumor-inducing ability of nononcogenic Agrobacteria as a result of plasmid transfer. Nature, London 255, 742-743.

Watson, B., Currier, T. C., Gordon, M. P., Chilton, M.-D. \& Nester, E. W. (1975). Plasmid required for virulence of Agrobacterium tumefaciens. Journal of Bacteriology 123, 255-264. 